\title{
Critically Discuss the Revival of Leptin for Obesity Therapy
}

\author{
Chi-Fai Lo ${ }^{1,2,3}$ \\ ${ }^{1}$ Institute of Theoretical Physics and Department of Physics, The Chinese University of Hong Kong, Hong Kong SAR, China \\ ${ }^{2}$ Department of Psychology, Sociology and Politics, Sheffield Hallam University, Sheffield S1 1WB, United Kingdom \\ ${ }^{3}$ Social and Human Sciences Section, SCOPE, City University of Hong Kong, Hong Kong SAR, China \\ Email: edcflo@gmail.com
}

How to cite this paper: Lo, C.-F. (2018). Critically Discuss the Revival of Leptin for Obesity Therapy. Psychology, 9, 217-228. https://doi.org/10.4236/psych.2018.92014

Received: January 10, 2018

Accepted: February 9, 2018

Published: February 12, 2018

Copyright (C) 2018 by author and Scientific Research Publishing Inc. This work is licensed under the Creative Commons Attribution International License (CC BY 4.0).

http://creativecommons.org/licenses/by/4.0/

\begin{abstract}
Obesity has created a very serious public health problem, and World Health Organisation has actually warned that there is an urgent need for multinational cooperation to stem the rise of obesity. More than 20 years ago the discovery of Leptin, which is an adipocyte-secreted hormone and primarily acts on the hypothalamic neurons to activate the regulation of energy homeostasis, created much interest in its potential use for the treatment of obesity, but the hope was soon lost after leptin failed to counteract common diet-induced obesity. In recent years some preclinical studies have surprisingly demonstrated that resistance to leptin can be reversed and the effects of leptin therapy can be amplified by several leptin sensitisers. This paper will critically discuss the plausible revival of leptin for obesity therapy with reference to research findings on various influencing factors contributing to the level of expression and secretion of leptin.
\end{abstract}

\section{Keywords}

Obesity, Energy Homeostasis, Leptin Difficency, Leptin Resistance, Leptin Sensitisers, Leptin Receptors

\section{Introduction}

The Body Mass Index (BMI) is a simple index of weight-for-height that is commonly used to classify overweight and obesity in adults. Adults with BMI $\geq 25$ are defined as being overweight, and those with BMI $\geq 30$ are obese (WHO, 2017). In accordance with a recent report of World Health Organization (WHO, 2016) obesity has become a serious global epidemic. In 2016 over 650 million adults aged 18 years and older were obese, meaning that the prevalence of obe- 
sity has almost tripled around the world for the past four decades. Obesity is the fifth leading risk for global deaths because numerous studies have shown that obesity is closely associated with various chronic diseases, namely type- 2 diabetes mellitus (Konner \& Bruning, 2012), cardiovascular diseases (Patel et al., 2008), immunity and inflammation (DeLany, 2008; Duntas \& Biondi, 2013), psychological deficits (Milaneschi et al., 2012; Yamada-Goto, et al., 2012), and some malignancy conditions (Pasquali \& Gambineri, 2006) such as colorectal cancer (Na \& Myung, 2012) and breast cancer (Wauman \& Tavernier, 2011). Thus, obesity has created a very serious public health problem, and medical costs associated with it are soaring high. In view of such an overwhelming health crisis, WHO (2016) has actually warned that there is an urgent need for multinational cooperation to stem the rise of obesity.

Leptin, which is an adipocyte-secreted hormone, was discovered more than 20 years and primarily acts on the hypothalamic neurons to activate the regulation of a balance between food intake and energy expenditure (Zhang et al., 1994; Halaas et al., 1995; Ingalls et al., 1996; Moon \& Friedman, 1997; Friedman \& Halaas, 1998). Obviously the discovery of leptin created much interest in its potential use for the treatment of obesity, but the hope was soon lost after leptin failed to counteract common diet-induced obesity (Halaas et al., 1997; Widdowson et al., 1997; Heymsfield et al., 1999; Levin et al., 2002). Nevertheless, overcoming resistance to the leptin therapy continues to challenge the researchers. In recent years some preclinical studies have surprisingly demonstrated that resistance to leptin can be reversed and the effects of leptin therapy can be amplified by several leptin sensitisers (Moon et al., 2011; Müller et al., 2012; Matthias, 2014; Crujeiras et al., 2015; Park \& Ahima, 2015). Accordingly, it is the aim of this paper to critically discuss the plausible revival of leptin for obesity therapy with reference to research findings on various influencing factors contributing to the level of expression and secretion of leptin.

\section{Energy Homeostasis and Leptin Deficiency}

Obesity is an eating disorder accompanied by an imbalance between energy consumed and energy expended. According to WHO (2017) the energy imbalance is attributed to both an increased consumption of energy-dense foods and an increase in physical inactivity. Both dieting and physical training have naturally become the most common behavioural weight loss programmes. However, none of these programmes has thus far proven to be effective in achieving the long-term weight loss (Kramer et al., 1989; Wooley \& Garner, 1994; Curioni \& Lourenco, 2005), implying that the exact causes of obesity are still unclear. A growing number of researchers have thus turned their attention to the study on the physiological mechanisms which normally regulate food intake and body weight, in the hope of identifying the real causes of obesity and discovering effective therapies (Maffei et al., 1995; Myers, et al., 2010; Wauman \& Tavernier, 2011; Myers, et al., 2012; Panariello et al., 2012; Wong et al., 2013; Ottaway et al., 
2015).

It is interesting that in most adults body weight is almost constant in spite of a large variation in daily food intake and energy expenditure (St-Pierre \& Tremblay, 2012). Indeed, body weight is generally maintained within a narrow range by regulating a balance between energy intake, in the form of food and drinks, and energy expenditure, in the form of basal metabolism, physical activity and adaptive thermogenesis, via the adipose-tissue-brain crosstalk (Schwartz et al., 2000; Rosen \& Spiegelman, 2006; Tao et al., 2011). When energy imbalance occurs, excessive calories accumulate as triglycerides in adipose tissue, leading to overweight and obesity. Hence, a better understanding of the energy homeostasis in a human body holds the key to finding the exact causes of obesity (Paspala et al., 2012; Szczesna et al., 2013; Chopra et al., 2014; Pan et al., 2014; Crujeiras et al., 2015; Park \& Ahima, 2015; Sáinz et al., 2015).

Energy homeostasis is a physiological process that controls energy balance via a complex interaction between the central nervous system (CNS) and peripheral tissues by constantly monitoring energy availability, storage and consumption (Morris \& Rui, 2009). The crucial player in the CNS controlling food intake is the hypothalamus located in the base of the brain (Elmquist et al., 1999; Cone, 2005). More specifically, ventromedial hypothalamus is associated with satiety and inhibiting food intake, whereas lateral hypothalamus is associated with hunger and increasing food intake. On the other hand, the adipocyte derived hormone leptin, that has proven to be a key marker of the energy storage in the body, provides the adiposity signals to the hypothalamus which subsequently integrates these signals and regulates the energy homeostasis by maintaining a balance between food intake and energy expenditure (Zhang et al., 1994; Halaas et al., 1995; Ingalls et al., 1996; Moon \& Friedman, 1997; Friedman and Halaas, 1998). Ample evidence has shown that genetic leptin deficiency or lack of functional leptin receptors in mice causes morbid obesity and type 2 diabetes (Zhang et al., 1994; Tartaglia et al., 1995) whilst congenital leptin deficiency results in severe hyperphagia and early-onset obsesity in humans (Montague et al., 1997; Strobel et al., 1998; Farooqi et al., 1999). In addition, a leptin replacement therapy significantly helps ameliorate obesity-associated metabolic disorders in those leptin-deficient patients (Zhang et al., 1994; Farooqi et al., 1999; Farooqi et al., 2002; Gibson et al., 2004; Licinio et al., 2004), thus confirming the leptin deficiency hypothesis and that normal leptin production and action are critical for maintaining energy balance.

\section{Leptin Therapy and Leptin Resistance}

In spite of the enormous hopes raised by the leptin therapy for human obesity, a large number of studies have demonstrated that most obese humans exhibit abnormally high levels of circulating leptin rather than a deficiency in leptin (Maffei et al., 1995; Considine et al., 1996; Scarpace et al., 2009) and that the administration of exogenous leptin fails to counteract common obesity (Halaas et al., 
1997; Widdowson et al., 1997; Heymsfield et al., 1999; Levin et al., 2002). These obese patients are hypothesized to develop leptin resistance that is commonly defined by the reduced capability of leptin to resist the development of obesity (Enriori et al., 2006; Morrison, 2008; Myers et al., 2008; Bjorbaek, 2009; Morris \& Rui, 2009; Wong et al., 2013). Since the lack of response to leptin hinders central and peripheral actions of leptin, including appetite, nutrient intestinal absorption, intermediate metabolism and insulin sensitivity, and subsequently leads to an energy imbalance and weight gains, much attention has been attracted to elucidating the underlying molecular mechanisms of leptin resistance and the possibility of correcting the resistance in the scientific community. Currently, although the actual underlying mechanisms remain subject to debate, two possible mechanisms have gained most attention to date, namely impairment in leptin transportation across the blood-brain barrier (BBB) and impairment in leptin signal transduction in the hypothalamic neurons (El-Haschimi et al., 2000; Morris et al., 2010; Coppari \& Bjorbaek, 2012). Besides, other factors, including inflammation or oxidative stress proceeses (Leon-Cabrera et al., 2013), a desensitization of cellular downstream signalling at central and peripheral level (Munzberg et al., 2005), and the type of diet (Shapiro et al., 2011), may also contribute to leptin resistance.

Extensive experimental results demonstrate that obese subjects exhibit high levels of peripheral leptin and relatively lower levels of leptin in cerebrospinal fluid (CSF), suggesting impairment in leptin transportation into the CNS across the BBB (Caro et al., 1996; Schwartz et al., 1996; El-Haschimi et al., 2000; Hileman et al., 2002; Banks \& Farrell, 2003; Levin et al., 2004). As leptin is a large molecule, a protein of $16 \mathrm{kDa}$, its transfer across the $\mathrm{BBB}$ is aided by a transport system. Thus, high circulating leptin levels in the obese condition may cause saturation of leptin transporters in the saturable transport system and compromise further leptin uptake by the brain (Caro et al., 1996). Since leptin mediates the signals for energy homeostasis (that is, inhibition of appetite and increased energy expenditure) only under the conditions that circulating leptin is transported across the $\mathrm{BBB}$ and ultimately binds to its receptors, the capability of leptin in regulation of appetite and energy expenditure is drastically reduced (El-Haschimi et al., 2000). As a result, the impaired leptin transport rates across the $\mathrm{BBB}$ have both chronic and acute influences on body weight. Moreover, the balance of leptin transport process is regulated by two leptin receptors (LEPRs), namely ObRa and ObRe. The ObRa mediates leptin transport across the BBB (Hileman et al., 2000; Tu et al., 2008) whereas the ObRe inhibits leptin transport by counteracting the function of ObRa (Bjorbaek et al., 2000). Under normal conditions the actions and numbers of both LEPRs are in balance. Accordingly, further studies to clarify the correlation between these two LEPRs under both normal and obese states are highly desirable for they will shed light on how to maintain the balance.

Another possible mechanism of leptin resistance is impairment in leptin sig- 
nal transduction in the hypothalamic neurons. It has been observed that administration of exogenous leptin produces strong immunoreactivity of phosphorylated signal transducer and activator of transcription 3 (STAT3) in the hypothalamic neurons of the arcuate nucleus (ARC) (Hubschle et al., 2001), and that in diet-induced obese mice leptin-induced STAT3 phosphorylation is greatly reduced in the hypothalamus (El-Haschimi et al., 2000). In response to leptin signalling, activated STAT3 in turn induces expression of the suppressor of cytokine signalling 3 (SOCS3) protein (Banks et al., 2000), which has been found to play an essential role in suppressing leptin signal transduction (Reed et al., 2010). Hence, enhanced hypothalamic SOCS3 expression is believed to be responsible for obesity-induced impairment of hypothalamic leptin signalling.

\section{Multi-Therapy of Leptin}

Beyond question leptin as a stand-alone drug is not capable of providing an effective treatment of obesity. However, in recent years researchers have demonstrated that a multi-therapy of leptin in combination with other leptin sensitisers may be able to improve peripheral leptin sensitivity and may hold therapeutic promise (Moon et al., 2011; Müller et al., 2012; Matthias, 2014; Crujeiras et al., 2015; Park \& Ahima, 2015). These leptin sensitisers target distinct neuroendocrine systems related to leptin signalling pathology. For instance, amylin and leptin, tri-infusion of cholecystokinin, leptin and amylin, and glucagon-like peptide 1 and leptin therapies are able to suppress food intake and enhance body weight loss than leptin monotherapy (Bhavsar et al., 1998; Roth et al, 2008; Trevaskis et al., 2008; Trevaskis et al., 2010; Yan et al, 2015). Alternatively, leptinrelated analogues which are capable of binding and activating the active leptin receptor OBR can be used to help solve some problems associated with natural leptin such as the issue of leptin being inactive, low stability and short half-life (Roujeau et al., 2014).

In addition, gastrointestinal derived peptides and a series of already approved pharmaco therapies have been found to amplify the weight-lowering actions of exogenous leptin (Wang et al., 2000; Kim et al., 2006; Roth et al., 2008; Unniappan \& Kieffer, 2008; Müller et al., 2012). Likewise, several research groups have investigated blocking those negative regulators of leptin signalling such as SOCS3 and the phosphor-tyrosine protein phosphatase PTP 1B to improve the leptin response in obese persons (Kaszubska et al., 2002; Reed et al., 2010; Roujeau et al., 2014). Furthermore, co-administration of leptin with either exendin-4 or FGF21 has been shown to restore leptin responsiveness in diet-induced obese mice (Kim et al., 2006; Müller et al.; 2012).

\section{Conclusion}

In spite of the impossibility of using leptin as a stand-alone magic bullet for obesity therapy, combination therapy for obesity seems to provide a glimpse of hope in pharmacotherapy. Since physiological mechanisms resisting weight loss are 
anticipated during leptin monotherapy, it is apparent that targeting more than one mechanism will naturally enhance the chance of success in the treatment of obesity. Hence, if we continue to work hard to advance our knowledge of the underlying mechanisms of leptin resistance steadily, the pursuit of identifying optimal combination therapies will become much more promising.

\section{Acknowledgements}

The author would like to thank Dr. Sue Jamison-Powell for her useful comments and suggestions.

\section{References}

Banks, W. A., \& Farrell, C. L. (2003). Impaired Transport of Leptin across the BloodBrain Barrier in Obesity Is Acquired and Reversible. American Journal of PhysiologyEndocrinology and Metabolism, 285, E10-E15. https://doi.org/10.1152/ajpendo.00468.2002

Banks, W. A., Davis, S. M., Bates, S. H., \& Myers, M. G. (2000). Activation of Downstream Signals by the Long Form of the Leptin Receptor. Journal of Biological Chemistry, 275, 14563-14572. https://doi.org/10.1074/jbc.275.19.14563

Bhavsar, S., Watkins, J., \& Young, A. (1998). Synergy between Amylin and Cholecystokinin for Inhibition of Food Intake in Mice. Physiology and Behavior, 64, 557-561. https://doi.org/10.1016/S0031-9384(98)00110-3

Bjorbaek, C. (2009). Central Leptin Receptor Action and Resistance in Obesity. Journal of Investigative Medicine, 57, 789-794. https://doi.org/10.2310/JIM.0b013e3181bb0d49

Bjorbaek, C., Lavery, H. J., Bates, S. H., Olson, R. K., Davis, S. M., Flier, J. S., \& Myers Jr., M. G. (2000). SOCS3 Mediates Feedback Inhibition of the Leptin Receptor via Tyr985. Journal of Biological Chemistry, 275, 40649-40657. https://doi.org/10.1074/jbc.M007577200

Caro, J. F., Kolaczynski, J. W., Nyce, M. R., Ohannesian, J. P., Opentanova, I., Goldman, W. H., Lynn, R. B., Zhang, P. L., Sinha, M. K., \& Considine, R. V. (1996). Decreased Cerebrospinal-Fluid/Serum Leptin Ratio in Obesity: A Possible Mechanism for Leptin Resistance. Lancet, 348, 159-161. https://doi.org/10.1016/S0140-6736(96)03173-X

Chopra, M., Siddhu, A., \& Tandon, N. (2014). Mechanism of Leptin Action, Resistance and Regulation of Energy Balance: A Review. Asian Journal of Multidisciplinary Studies, 2, 224-234.

Cone, R. D. (2005). Anatomy and Regulation of the Central Melanocortin System. Nature Neuroscience, 8, 571-578. https://doi.org/10.1038/nn1455

Considine, R. V., Sinha, M. K., Heiman, H. L., Kriauciunas, A., Stephens, T. W., Mark, R. N., Ohannesian, J. P., Marco, C. C., McKee, L. J., Bauer, T. L., \& Caro, J. F. (1996). Serum Immunoreactive-Leptin Concentrations in Normal-Weight and Obese Humans. New England Journal of Medicine, 334, 292-295. https://doi.org/10.1056/NEJM199602013340503

Coppari, R., \& Bjorbaek, C. (2012). Leptin Revisited: Its Mechanism of Action and Potential for Treating Diabetes. Nature Reviews Drug Discovery, 11, 692-708. https://doi.org/10.1038/nrd3757

Crujeiras, A. B., Carreira, M. C., Cabia, B., Andrade, S., Amil, M., \& Casanueva, F. F. (2015). Leptin Resistance in Obesity: An Epigenetic Landscape. Life Sciences, 140, $57-$ 63. https://doi.org/10.1016/j.lfs.2015.05.003 
Curioni, C. C., \& Lourengo, P. M. (2005). Long-Term Weight Loss after Diet and Exercise: A Systematic Review. International Journal of Obesity, 29, 1168-1174. https://doi.org/10.1038/sj.ijo.0803015

DeLany, J. (2008). Leptin Hormone and Other Biochemical Influences on Systemic Inflammation. Journal of Bodywork \& Movement Therapies, 12, 121-132. https://doi.org/10.1016/j.jbmt.2007.11.006

Duntas, L. H., \& Biondi, B. (2013). The Interconnections between Obesity, Thyroid Function, and Autoimmunity: The Multifold Role of Leptin. Thyroid, 23, 646-653. https://doi.org/10.1089/thy.2011.0499

El-Haschimi, K., Pierroz, D. D., Hileman, S. M., Bjorbaek, C., \& Flier, J. S. (2000). Two Defects Contribute to Hypothalamic Leptin Resistance in Mice with Diet-Induced Obesity. Journal of Clinical Investigation, 105, 1827-1832. https://doi.org/10.1172/JCI9842

Elmquist, J. K., Elias, C. F., \& Saper, C. B. (1999). From Lesions to Leptin: Hypothalamic Control of Food Intake and Body Weight. Neuron, 22, 221-232. https://doi.org/10.1016/S0896-6273(00)81084-3

Enriori, P. J., Evans, A. E., Sinnayah, P., \& Cowley, M. A. (2006). Leptin Resistance and Obesity. Obesity, 14, 254-258. https://doi.org/10.1038/oby.2006.319

Farooqi, I. S., Jebb, S. A., Langmack, G., Lawrence, E., Cheetham, C. H., Prentice, A. M., Hughes, I. A., McCamish, M. A., \& O'Rahilly, S. (1999). Effects of Recombinant Leptin Therapy in a Child with Congenital Leptin Deficiency. The New England Journal of Medicine, 341, 879-884. https://doi.org/10.1056/NEJM199909163411204

Farooqi, I. S., Matarese, G., Lord, G. M., Keogh, J. M., Lawrence, E., Agwu, C., Sanna, V., Jebb, S. A., Perna, F., Fontana, S., Lechler, R. I., DePaoli, A. M., \& O'Rahilly, S. (2002). Beneficial Effects of Leptin on Obesity, T Cell Hyporesponsiveness, and Neuroendocrine/Metabolic Dysfunction of Human Congenital Leptin Deficiency. Journal of Clinical Investigation, 110, 1093-1103. https://doi.org/10.1172/JCI0215693

Friedman, J. M., \& Halaas, J. L. (1998). Leptin and the Regulation of Body Weight in Mammals. Nature, 395, 763-770. https://doi.org/10.1038/27376

Gibson, W. T., Farooqi, I. S., Moreau, M., DePaoli, A. M., Lawrence, E., O'Rahilly, S., \& Trussell, R. A. (2004). Congenital Leptin Deficiency Due to Homozygosity for the Delta133G Mutation: Report of Another Case and Evaluation of Response to Four Years of Leptin Therapy. The Journal of Clinical Endocrinology \& Metabolism, 89, 4821-4826. https://doi.org/10.1210/jc.2004-0376

Halaas, J. L., Boozer, C., Blair-West, J., Fidahusein, N., Denton, D. A., \& Friedman, J. M. (1997). Physiological Response to Long-Term Peripheral and Central Leptin Infusion in Lean and Obese Mice. Proceedings of the National Academy of Sciences of the United States of America, 94, 8878-8883. https://doi.org/10.1073/pnas.94.16.8878

Halaas, J. L., Gajiwala, K. S., Maffei, M., Cohen, S. L., Chait, B. T., Rabinowitz, D., Lallone, R. L., Burley, S. K., \& Friedman, J. M. (1995). Weight-Reducing Effects of the Plama Protein Encoded by the Obese Gene. Science, 269, 543-546.

https://doi.org/10.1126/science.7624777

Heymsfield, S. B., Greenberg, A. S., Fujioka, K., Dixon, R. M., Kushner, R., Hunt, T., Lubina, J. A., Patane, J., Self, B., Hunt, P., \& McCamish, M. (1999). Recombinant Leptin for Weight Loss in Obese and Lean Adults: A Randomized, Controlled, DoseEscalation Trial. JAMA, 282, 1568-1575. https://doi.org/10.1001/jama.282.16.1568

Hileman, S. M., Pierroz, D. D., Masuzaki, H., Bjorbaek, C., El-Haschimi, K., Banks, W. A., \& Flier, J. S. (2002). Characterization of Short Isoforms of the Leptin Receptor in Rat Cerebral Microvessels and of Brain Uptake of Leptin in Mouse Models of Obesity. En- 
Hileman, S. M., Tornoe, J., Flier, J. S., \& Bjorbaek, C. (2000). Transcellular Transport of Leptin by Short Leptin Receptor Isoform ObRa in Madin-Darby Canine Kidney Cells. Endocrinology, 141, 1955-1961. https://doi.org/10.1210/endo.141.6.7450

Hubschle, T., Thom, E., Watson, A., Roth, J., Klaus, S., \& Meyerhof, W. (2001). Leptin-Induced Nuclear Translocation of STAT3 Immunoreactivity in Hypothalamic Nuclei Involved in Body Weight Regulation. Journal of Neuroscience, 21, 2413-2424.

Ingalls, A. M., Dickie, M. M., \& Snell, G. D. (1996). Obese, A New Mutation in the House Mouse. Obesity Research \& Clinical Practice, 4, 101. https://doi.org/10.1002/j.1550-8528.1996.tb00519.x

Kaszubska, W., Falls, H. D., Schaefer, V. G., Haasch, D., Frost, L., Hessler, P., Kroeger, P. E., White, D. W., Jirousek, M. R., \& Trevillyan, J. M. (2002). Protein Tyrosine Phosphatase 1B Negatively Regulates Leptin Signalling in a Hypothalamic Cell Line. Mo lecular and Cellular Endocrinology, 195, 109-118.

Kim, Y. W., Kim, J. Y., Park, Y. H., Park, S. Y., Won, K. C., Choi, K. H., Hub, J. Y., \& Moon, K. H. (2006). Metformin Restores Leptin Sensitivity in High-Fat-Fed Obese Rats with Leptin Resistance. Diabetes, 55, 716-724. https://doi.org/10.2337/diabetes.55.03.06.db05-0917

Konner, A. C., \& Bruning, J. C. (2012). Selective Insulin and Leptin Resistance in Metabolic Disorders. Cell Metabolism, 16, 144-152. https://doi.org/10.1016/j.cmet.2012.07.004

Kramer, F. M., Jeffery, R. W., Forster, J. L., \& Snell, M. K. (1989). Long-Term Follow-Up of Behavioral Treatment for Obesity: Patterns of Weight Regain among Men and Women. International Journal of Obesity, 13, 123-136.

Leon-Cabrera, S., Solis-Lozano, L., Suarez-Alvarez, K., Gonzalez-Chavez, A., Bejar, Y. L., Robles-Diaz, G., \& Escobedo, G. (2013). Hyperleptinemia Is Associated with Parameters of Low-Grade Systemic Inflammation and Metabolic Dysfunction in Obese Human Beings. Frontiers in Integrative Neuroscience, 7, 62. https://doi.org/10.3389/fnint.2013.00062

Levin, B. E., \& Dunn-Meynell, A. A. (2002). Reduced Central Leptin Sensitivity in Rats with Diet-Induced Obesity. American Journal of Physiology Regulatory Integrative \& Comparative Physiology, 283, R941-R948. https://doi.org/10.1152/ajpregu.00245.2002

Levin, B. E., Dunn-Meynell, A. A., \& Banks, W. A. (2004). Obesity-Prone Rats Have Normal Blood-Brain Barrier Transport but Defective Central Leptin Signaling before Obesity Onset. American Journal of Physiology Regulatory Integrative \& Comparative Physiology, 286, 143-150. https://doi.org/10.1152/ajpregu.00393.2003

Licinio, J., Caglayan, S., Ozata, M., Yildiz, B. O., De Miranda, P. B., O'Kirwan, F., Whitby, R., Liang, L., Cohen, P., Bhasin, S., Krauss, R. M., Veldhuis, J. D., Wagner, A. J., DePaoli, A. M., McCann, S. M., \& Wong, M. L. (2004). Phenotypic Effects of Leptin Replacement on Morbid Obesity, Diabetes Mellitus, Hypogonadism, and Behavior in Leptin-Deficient Adults. Proceedings of the National Academy of Sciences of the United States of America, 101, 4531-4536. https://doi.org/10.1073/pnas.0308767101

Maffei, M., Halaas, J., Ravussin, E., Pratley, R. E., Lee, G. H., Zhang, Y., Fei, H., Kim, S., Lallone, R., Ranganathan, S., Kern, P. A., \& Friedman, J. M. (1995). Leptin Levels in Human and Rodent: Measurement of Plasma Leptin and Ob RNA in Obese and Weight-Reduced Subjects. Nature Medicine, 1, 1155-1161. https://doi.org/10.1038/nm1195-1155

Matthias, B. (2014). Adipokines-Removing Road Blocks to Obesity and Diabetes Therapy. Molecular Metabolism, 3, 230-240. https://doi.org/10.1016/j.molmet.2014.01.005

Milaneschi, Y., Simonsick, E. M., Vogelzangs, N., Strotmeyer, E. S., Yaffe, K., Harris, T. 
B., Tolea, M. I., Ferrucci, L., \& Penninx, B. W. (2012). Leptin, Abdominal Obesity, and Onset of Depression in Older Men and Women. Journal of Clinical Psychiatry, 73, 1205-1211. https://doi.org/10.4088/JCP.11m07552

Montague, C. T., Farooqi, I. S., Whitehead, J. P., Soos, M. A., Rau, H., Wareham, N. J., Sewter, C. P., Digby, J. E., Mohammed, S. N., Hurst, J. A., Cheetham, C. H., Earley, A. R., Barnett, A. H., Prins, J. B., \& O'Rahilly, S. (1997). Congenital Leptin Deficiency Is Associated with Severe Early-Onset Obesity in Humans. Nature, 387, 903-908.

Moon, B. C., \& Friedman, J. M. (1997). The Molecular Basis of the Obese Mutation in ob2j Mice. Genomics, 42, 152-156. https://doi.org/10.1006/geno.1997.4701

Moon, B. C., Chamberland, J. P., Diakopoulos, K. N., Florenza, C. G., Ziemke, F., Schneider, B., \& Mantzoros, C. S. (2011). Leptin and Amylin Act in an Additive Manner to Activate Overlapping Signalling Pathways in Peripheral Tissues: In Vitro and ex Vivo Studies in Humans. Diabetes Care, 34, 132-138. https://doi.org/10.2337/dc10-0518

Morris, D. L., \& Rui, L. (2009). Recent Advances in Understanding Leptin Signalling and Leptin Resistance. American Journal of Physiology Regulatory Integrative \& Comparative Physiology, 297, E1247-E1259.

Morris, D. L., Cho, K. W., \& Rui, L. (2010). Critical Role of Src Homology 2 (SH2) Domain of Neuronal SH2B1 in the Regulation of Body Weight and Glucose Homeostasis in Mice. Endocrinology, 151, 3643-3651. https://doi.org/10.1210/en.2010-0254

Morrison, C. D. (2008). Leptin Resistance and the Response to Positive Energy Balance. Physiology \& Behavior, 94, 660-663. https://doi.org/10.1016/j.physbeh.2008.04.009

Müller, T. D., Sullivan, L. M., Habegger, K., Yi, C. X., Kabra, D., Grant, E., Ottaway, N., Krishna, R., Holland, J., Hembree, J., Perez-Tilve, D., Pfluger, P. T., DeGuzman, M. J., Siladi, M. E., Kraynov, V. S., Axelrod, D. W., DiMarchi, R., Pinkstaff, J. K., \& Tschöp, M.H. (2012). Restoration of Leptin Responsiveness in Diet-Induced Obese Mice Using an Optimized Leptin Analog in Combination with Exendin-4 of FGF21. Journal of Peptide Science, 18, 383-393. https://doi.org/10.1002/psc.2408

Munzberg, H., Bjornholm, M., Bates, S. H., \& Myers Jr., M. G. (2005). Leptin Receptor Action and Mechanisms of Leptin Resistance. Cellular and Molecular Life Sciences, 62, 642-652. https://doi.org/10.1007/s00018-004-4432-1

Myers Jr., M. G., Cowley, M. A., \& Munzberg, H. (2008). Mechanisms of Leptin Action and Leptin Resistance. Annual Review of Physiology, 70, 537-556. https://doi.org/10.1146/annurev.physiol.70.113006.100707

Myers Jr., M. G., Heymsfield, S. B., Haft, C., Kahn, B. B., Laughlin, M., Leibel, R. L., Tschöp, M. H., \& Yanovski, J. A. (2012). Challenges and Opportunities of Defining Clinical Leptin Resistance. Cell Metabolism, 15, 150-156.

https://doi.org/10.1016/j.cmet.2012.01.002

Myers Jr., M. G., Leibel, R. L., Seeley, R. J., \& Schwartz, M. W. (2010). Obesity and Leptin Resistance: Distinguishing Cause from Effect. Trends in Endocrinology and Metabolism, 21, 643-651. https://doi.org/10.1016/j.tem.2010.08.002

Na, S. Y., \& Myung, S. J. (2012). Obesity and Colorectal Cancer. The Korean Journal of Gastroenterology, 59, 16-26. https://doi.org/10.4166/kjg.2012.59.1.16

Ottaway, N., Mahbod, P., Rivero, B., Norman, L. A., Gerler, A., D’Alessio, D. A., \& Perez-Tilve, D. (2015). Diet-Induced Obese Mice Retain Endogenous Leptin Action. Cell Metabolism, 21, 877-882. https://doi.org/10.1016/j.cmet.2015.04.015

Pan, H., Guo, J., \& Su, Z. (2014). Advances in Understanding the Interrelations between Leptin Resistance and Obesity. Physiology and Behavior, 130, 157-169.

https://doi.org/10.1016/j.physbeh.2014.04.003 
Panariello, F., Polsinelli, G., Borlido, C., Monda, M., \& De Luca, V. (2012). The Role of Leptin in Antipsychotic-Induced Weight Gain: Genetic and Non-Genetic Factors. Journal of Obesity, 2012, Article ID: 572848. https://doi.org/10.1155/2012/572848

Park, H. K., \& Ahima, R.S. (2015). Physiology of Leptin: Energy Homeostasis, Neuroendocrine Function and Metabolism. Metabolism: Clinical and Experimental, 64, 24-34. https://doi.org/10.1016/j.metabol.2014.08.004

Paspala, I., Katsiki, N., Kapoukranidou, D., Mikhailidis, D., \& Tsiligiroglou-Fachantidou, A. (2012). The Role of Psychological and Neuroendocrine Mechanisms in Appetite Regulation and Obesity. The Open Cardiovascular Medicine Journal, 6, 147-155. https://doi.org/10.2174/1874192401206010147

Pasquali, R., \& Gambineri, A. (2006). Metabolic Effects of Obesity on Reproduction. Reproductive Biomedicine Online, 12, 542-551. https://doi.org/10.1016/S1472-6483(10)61179-0

Patel, S. B., Reams, G. P., Spear, R. M., Freeman, R. H., \& Villarreal, D. (2008). Leptin: Linking Obesity, the Metabolic Syndrome, and Cardiovascular Disease. Current Hypertension Reports, 10, 131-137. https://doi.org/10.1007/s11906-008-0025-y

Reed, A., Unger, E., Olofsson, L., Piper, M., Myers, M., \& Xu, A. (2010). Functional Role of Suppressor of Cytokine Signalling 3 Upregulation in Hypothalamic Leptin Resistance and Long-Term Energy Homeostasis. Diabetes, 59, 894-906.

https://doi.org/10.2337/db09-1024

Rosen, E. D., \& Spiegelman, B. M. (2006). Adipocytes as Regulators of Energy Balance and Glucose Homeostasis. Nature, 444, 847-853. https://doi.org/10.1038/nature05483

Roth, J. D., Roland, B. L., Cole, R. L., Trevaskis, J. L., Weyer, C., Koda, J. E., Anderson, C. M., Parkes, D. G., \& Baron, A. D. (2008). Leptin Responsiveness Restored by Amylin agonism in Diet-Induced Obesity: Evidence from Nonclinical and Clinical Studies. Proceedings of the National Academy of Sciences of the United States of America, 105, 7257-7262. https://doi.org/10.1073/pnas.0706473105

Roujeau, C., Jockers, R., \& Dam, J. (2014). New Pharmacological Perspectives for the Leptin Receptor in the Treatment of Obesity. Frontier in Endocrinology, 5, 167. https://doi.org/10.3389/fendo.2014.00167

Sáinz, N., Barrenetxe, J., Moreno-Aliaga, M., \& Martinez, J.A. (2015). Leptin Resistance and Diet-Induced Obesity: Central and Peripheral Actions of Leptin. Metabolism: Clinical and Experimental, 64, 35-46. https://doi.org/10.1016/j.metabol.2014.10.015

Scarpace, P. J., \& Zhang, Y. (2009). Leptin Resistance: A Predisposing Factor for Diet-Induced Obesity. American Journal of Physiology Regulatory Integrative \& Comparative Physiology, 296, R493-500. https://doi.org/10.1152/ajpregu.90669.2008

Schwartz, M. W., Peskind, E., Raskind, M., Boyko, E. J., \& Porte, D. J. (1996). Cerebrospinal Fluid Leptin Levels: Relationship to Plasma Levels and to Adiposity in Humans. Nature Medicine, 2, 589-593. https://doi.org/10.1038/nm0596-589

Schwartz, M. W., Woods, S. C., Porte, D., Seeley, R. J., \& Baskin, D. G. (2000). Central Nervous System Control of Food Intake. Nature, 404, 661-671.

https://doi.org/10.1038/35007534

Shapiro, A., Turner, N., Gao, Y., Cheng, K. Y., \& Scarpace, P. J. (2011). Prevention and Reversal of Diet-Induced Leptin Resistance with a Sugar-Free Diet Despite High Fat Content. British Journal of Nutrition, 106, 390-397. https://doi.org/10.1017/S000711451100033X

St-Pierre, J., \& Tremblay, M. L. (2012). Modulation of Leptin Resistance by Protein Tyrosine Phosphatases. Cell Metabolism, 15, 292-297.

Strobel, A., Issad, T., Camoin, L., Ozata, M., \& Strosberg, A. D. (1998). A Leptin Missense 
Mutation Associated with Hypogonadism and Morbid Obesity. Nature Genetics, 18, 213-215. https://doi.org/10.1038/ng0398-213

Szczesna, M., Kirsz, K., Kucharski, M., Szymaszek, P., \& Zieba, D. A. (2013). Obesity and Leptin Resistance: The Role of Growth Hormone. Health, 5, 29-39. https://doi.org/10.4236/health.2013.58A3005

Tao, Y., Zhang, H., Gao, B., Guo, J., Hu, Y., \& Su, Z. (2011). Water-Soluble Chitosan Nanoparticles Inhibit Hypercholesterolemia Induced by Feeding a High-Fat Diet in Male Sprague-Dawley Rats. Journal of Nanomaterials, 10, 1-5. https://doi.org/10.1155/2011/814606

Tartaglia, L.A., Dembski, M., Weng, X., Deng, N., Culpepper, J., Devos, R., Richards, G. J., Campfield, L. A., Clark, F. T., Deeds, J., Muir, C., Sanker, S., Moriarty, A., Moore, K. J., Smutko, J. S., Mays, G. G., Wool, E. A., Monroe, C. A., \& Tepper, R. I. (1995). Identification and Expression Cloning of a Leptin Receptor. Leptin Receptor, 83, 1263-1271.

Trevaskis, J. L., Coffey, T., Cole, R., Lei, C., Wittmer, C., Walsh, B., Weyer, C., Koda, J., Baron, A. D., Parkes, D. G., \& Roth, J. D. (2008). Amylin-Mediated Restoration of Leptin Responsiveness in Diet-Induced Obesity: Magnitude and Mechanisms. Endocrinology, 149, 5679-5687. https://doi.org/10.1210/en.2008-0770

Trevaskis, J. L., Turek, V. F., Griffin, P. S., Wittmer, C., Parkes, D. G., \& Roth, J. D. (2010). Multi-Hormonal Weight Loss Combinations in Diet-Induced Obese Rats: Therapeutic Potential of Cholecystockinin? Physiology and Behavior, 100, 187-195. https://doi.org/10.1016/j.physbeh.2010.02.023

Tu, H., Kastin, A. J., Hsuchou, H., \& Pan, W. (2008). Soluble Receptor Inhibits Leptintransport. Journal of Cellular Physiology, 214, 301-305.

Unniappan, S., \& Keiffler, T.J. (2008) Leptin Extends the Anorectic Effects of Chronic PYY(3-36) Administration in Ad Libitum-Fed Rats. American Journal of Physiology Regulatory Integrative \& Comparative Physiology, 295, R51-R58. https://doi.org/10.1152/ajpregu.00234.2007

Wang, L, Barachina, M. D., Martinez, V., Wei, J. Y., \& Tache, Y. (2000). Synergistic Interaction between CCK and Leptin to Regulate Food Intake. Regulatory Peptides, 92, 79-85. https://doi.org/10.1016/S0167-0115(00)00153-1

Wauman, J., \& Tavernier, J. (2011). Leptin Receptor Signaling Pathways to Leptin Resistance. Frontiers in Bioscience, 16, 2771-2793. https://doi.org/10.2741/3885

Widdowson, P. S., Upton, R., Buckingham, R., Arch, J., \& Williams, G. (1997). Inhibition of Food Response to Intracerebroventricular Injection of Leptin Is Attenuated in Rats with Diet-Induced Obesity. Diabetes, 46, 1782-1785.

https://doi.org/10.2337/diab.46.11.1782

Wong, I. P., Nguyen, A. D., Khor, E. C., Enriquez, R. F., Eisman, J. A., Sainsbury, A., Herzoq, H., \& Baldock, P. A. (2013). Neuropeptide Y Is a Critical Modulator of Leptin's Regulation of Cortical Bone. Journal of Bone and Mineral Research, 28, 886898. https://doi.org/10.1002/jbmr.1786

Wooley, S. C., \& Garner, D. M. (1994). Dietary Treatments for Obesity Are Ineffective. BMJ: British Medical Journal, 309, 655-656. https://doi.org/10.1136/bmj.309.6955.655

World Health Organisation (2016). Report of the Commission on Ending Childhood Obesity. Available from: www.who.int/end-childhood-obesity/publications/echo-report/en/

World Health Organisation (2017). Fact Sheet on "Obesity and overweight". Available from: http://www.who.int/mediacentre/factsheets/fs311/en/

Yamada-Goto, N., Katsura, G., Ochi, Y., \& Nakao, K. (2012). An Approach toward CNS 
Dysfunction Associated with Metabolic Syndrome; Implication of Leptin, Which Is a Key Molecule of Obesity, in Depression Associated with Obesity. Nihon Shinkei Seishin Yakurigaku Zasshi, 32, 245-250.

Yan, C., Yang, Y., Saito, K., Zu, P., Wang, C., Hinton Jr., A.O., Yan, X., Wu, Q., Tong, Q., Elmquist, J.K., Fukuda, M., \& Xu, Y. (2015). Meta-Chlorophenylpiperazine Enhances Leptin Sensitivity in Diet-Induced Obese Mice. British Journal of Pharmacology, 172, 350-3521. https://doi.org/10.1111/bph.13141

Zhang, Y., Proenca, R., Maffei, M., Barone, M., Leopold, L., \& Friedman, J.M. (1994). Positional Cloning of the Mouse Obese Gene and Its Human Homologue. Nature, 372, 425-432. https://doi.org/10.1038/372425a0 